DOI: https://doi.org/10.31933/dijdbm.v2i2 Received: $22^{\text {nd }}$ December 2020, Revised: $22^{\text {nd }}$ January 2021, Publish: $28^{\text {th }}$ February 2021

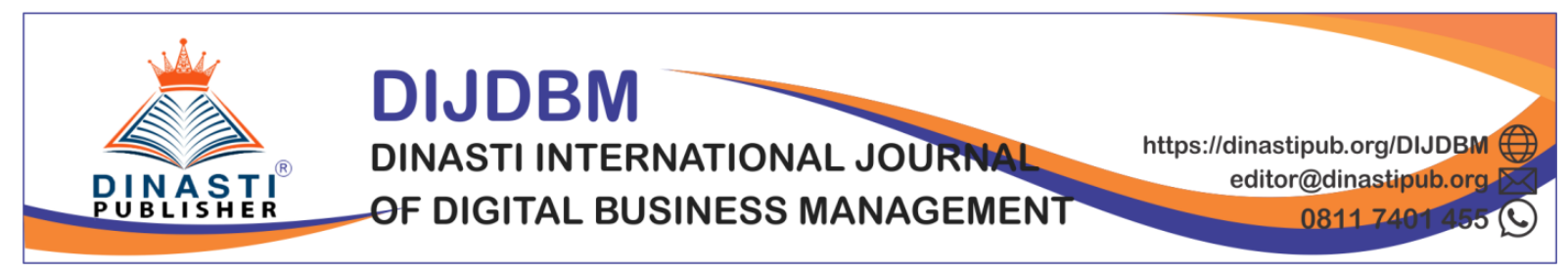

\title{
MODEL PERCEIVED RISK AND TRUST: E-WOM AND PURCHASE INTENTION (THE ROLE OF TRUST MEDIATING IN ONLINE SHOPPING IN SHOPEE INDONESIA)
}

\author{
Ridho Rafqi Ilhamalimy ${ }^{1}$, Hapzi Ali² \\ 1) Student of Universitas Mercu Buana, Jakarta, rafqiridho@gmail.com \\ 2) Senior Lecturer of Universitas Mercu Buana, Jakarta, hapzi.ali@gmail.com
}

\begin{abstract}
Purpose. This study discusses the Role of Trust in Mediating eWOM and Perceived Risk of Online Purchase Intention in Shopee. Design / methodology / approach. This study was conducted in Jakarta using 185 samples using SEM-PLS data analysis method. Findings. Trust is able to act as mediating between ewom and also perceived risk of online purchase intention in shopee. Practical implication. Shopee companies should be able to provide reliability in services and various features, and also increase security when consumers shop online at Shopee, because it can create an interest in buying online on an ongoing basisTheoretical implications. This research has limitations that can be used as advice or input for further research.
\end{abstract}

Keywords: Perceived Risk, Trust, e-WOM, Purchase Intention.

\section{INTRODUCTION}

The growth of E-commerce in Indonesia is very rapid because it is influenced by the style of online shopping, especially millennials. Google's latest research included in the SEA e-Conomy 2018 report shows Indonesia is ranked first in the southeast Asia region for digital economic transactions, with Indonesia contributing 49 percent (Rahayu, 2019).

In Indonesia there are many e-commerce sites or digital platforms such as Lazada, Tokopedia, Blibli.com, Jd id, Bukalapak and Shopee Indonesia. Six of the most visited online retail products consumer needs sites in Indonesia is Shopee is ranked first with a total web visitors per month of 72 million visitors. The next rank is Tokopedia 67 million visitors and Bukalapak 39 million visitors, then Lazada, blibli and jdid at the bottom. Related to this, in business competition strategy accuracy is an important factor for businesses that lead to the effectiveness of decision making in the future in order to create competitive advantages (Permana, 2017). 


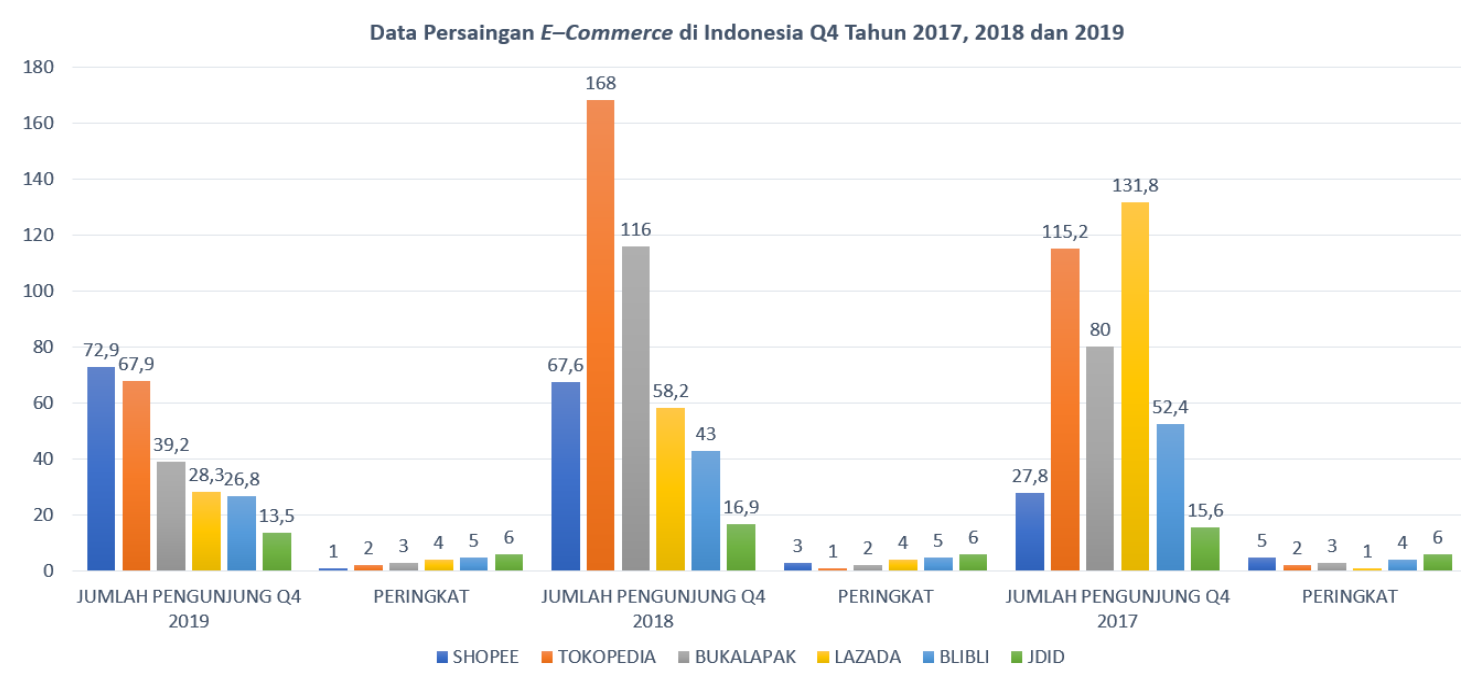

Figure 1. Data on E-Commerce Competition in Indonesia Q4 2017, 2018 and 2019 Sumber: iPrice.co.id (2019)

Online shopping is an easy solution to busy life in today's world. Online shopping can save you so much time, because you don't want to spend a lot of time shopping (Rahman et al., 2018). Businesses by utilizing the internet have advantages and disadvantages, where the advantages, namely requiring relatively affordable capital and can reach the market more broadly, while the weakness, namely the difficulty of building consumer confidence in making online purchasing decisions (Ali \& Tonny Wangdra, 2010). The growth of internet usage and digitalization in social form has a significant impact on changing trends and consumer spending behavior (Han et al., 2018). There are striking differences between online and offline shoppers and variations in purchasing behavior between online consumers (Arce-Urriza et al., 2017), influenced by the various promotions offered thus creating a buying interest that leads to purchasing decisions (Sivaram et al., 2019). The use of the internet to collect information, cendrung generate interest in making online purchases (Hung et al., 2019). Online consumer behavior in finding product information indicates a tendency to have an interest in buying before deciding to make a purchase. Consumers tend to like to search for information using the internet when shopping for products online (Han et al, 2018).

Some previous research has examined many factors that influence the intention to buy online. The intention of purchase is formed when perceived risk has fewer consequences (Ariffin et al., 2018) As is the case (Hamid et al, 2016) found that risk perception, application design and trust also influenced purchasing intentions. Trust is achieved when the perceived risk perception is lower than expected (Farivar et al., 2017), and trust is also influenced by ewom (Jalilvand et al., 2017). Other research finds e-wom can also affect buying interest (Abubakar \& Ilkan, 2016). Another case with (Lee et al., 2017) e-wom has no effect on buying interest. It was later discovered that the intention of buying online can be influenced by celebrity beliefs, celebrity expertise, celebrity appeal (Murwaningtyas et al. 2019), ease and quality of products (Indrajaya \& Ali, 2017).

Social benefits and trust affect online buying interests (Liu \& Guo, 2017). Pudaruth \& Nursing, (2017) finding the ease of influencing buying interest. (Silva et al., 2019) found that trust has the ability to dissor any perceived risk to online buying interest, then from a different perspective the trust is also able to mediate e-wom against online buying interests (Bhandari \& 
Rodgers, 2018). Where eWOM, public relations and clans are part of a promotion that can increase brand equity and can increase interest in online purchases (Munawar \& Ali, 2017). Trust is often used as a mediation variable by previous studies, where previously those who had reviewed mediation variables were found by (Baron \& Kenny, 1986) states certain variables are said to have a function as mediation to the extent that it explains the relationship between predictors and criteria. Trust variables have been developed by (Silva et al., 2019) previously made trust variables as mediation between risk perception and ewom on online buying interest, and from different perspectives (Bhandari \& Rodgers, 2018) found that trust variables are able to mediate between e-wom to online buying interests. Based on what has been described, the importance of this research examines more deeply about "The Role of Trust in Mediating eWOM and Perceived Risk of Online Purchase Intention in Shopee”.

\section{RESEARCH PURPOSES}

Based on the formulation of the research problem, the objectives of this study can be determined, namely to analyze:

1. The effect of ewom on purchase intention.

2. The effect of perceived risk on online purchase intention.

3 . The effect of trust on online purchase intention.

4. The effect of ewom on trust.

5. The effect of risk perception on trust.

6. The effect of ewom on online purchase intention is mediated by trust

7. The effect of risk perception on online purchase intention is mediated by trust.

\section{LITERATURE REVIEW}

Hypothesis testing research is a study that aims to develop hypotheses and test them empirically (Ali \& Limakrisna, 2013). This study discusses how the relationship between ewom, perceived risk and trust to buying interest, where variable trust in this research as mediation between ewom and risk perception to buy interest. The development of this research hypothesis is based on several previous research results as a reference in building conceptual research design.

\section{Purchase Intention}

Schiffman \& Kanuk (2012) interest is one of the psychological aspects that have an influence on attitudes and behaviors. In "Theory of Reasoned Action (TRA) describes how behaviors that change based on the results of behavioral intentions, and behavioral intentions can be influenced by social norms and individual attitudes towards behavior" (Eagle et al., 2013). As for (Lee \& Kotler, 2011) "Theory of Reason Action is the best prediction about a person's behavior based on the person's interests. Behavioral interest is based on 2 main factors, namely: the individual's trust in the outcome of the behavior carried out and the individual's perception of the views of those closest to the individual towards the behavior carried out". Can be concluded buying interest is an attitude based on the trust and perception of the individual after receiving information and ransangan from a product to make a purchase. If consumers have a strong knowledge of product information can create buying interest in the future. This study adopts indicators from several relevant previous studies, such as (Yang et 
al., 2015) using three indicators in megkurur purchase intention namely: 1) the possibility of continuing to buy; 2) consideration in making a purchase; and 3) willingness to buy.

\section{INFLUENCE BETWEEN VARIABLES 1. eWOM on Purchase Intention}

Dissemination of information through internet media with the term eWOM (Electronic Word of Mouth), where consumers provide information to other consumers through internet media (Schiffman \& Kanuk, 2012). Silverman (2011) Word of Mouth Marketing can help consumers in the purchasing decision process as an alternative assessment. Word of Mouth Marketing plays an important role, because information about products is directly obtained from trusted consumers, such as friends, family or experts. In line with the theory (Kotler \& Keller, 2013) that Word of Mouth Marketing can greatly influence the purchasing decision process. eWOM is an ongoing information exchange peroses between potential, actual or experienced consumers regarding a product, brand, service or company, available over the internet (Ismagilova et al., 2017). It can be concluded that Ewom is an information obtained through internet media can help consumers in purchasing behavior. The information is the result of a word-of-mouth evaluation through internet media that provides a variety of alternative consumers to compare the performance of a product or service recommended by individuals and organizations that can influence buying interest. Research developed (Matute et al., 2016) use three indicators in measuring ewom, including : 1) eWOM Quantitiy; 2) eWOM Credibility; dan 3) eWOM Quality.

The relationship between ewom and buying interest is based on previous research. Like the research developed (Abubakar \& Ilkan, 2016) find that eWOM may affect purchase intention. The same is the case (Erkan \& Evans, 2016) ewom has a positive effect and significant on buying interest. As is the case (Bataineh, 2015) find ewom factors that have a positive influence and significant on purchase intention, including: quality of eWOM, credibility of eWOM, and quantity of eWOM. Other research results by (Lee et al., 2017) found that word of mouth internet information has no effect on purchase intention. Based on the description of the results of previous research can be hypothesized, that:

H1 : eWOM has a positive and significant effect on purchase intention.

\section{Perceived Risk on Purchase Intention}

Perceived risks, The absence of perceived risks by consumers will affect consumer behavior (Schiffman \& Kanuk, 2012). While (Firdayanti, 2012) defines the perception of risk as a way for consumers to perceive the possibility of losses that will be obtained from their decisions as a result of the uncertainty of the matter being decided. Suryani (2013) perception of risk is like the uncertainty faced by consumers when they are unable to see the uncertainty that occurs due to the purchasing behavior that will be done. The conclusion is that the risk that is perceived when consumers make purchases online is a consideration to reduce the consequences or uncertainties received. So by reducing the risk that is perceived can cause consumer interest in buying. Research developed by (Ariffin et al., 2018) menggunakan 
Indikator - indikator yang digunakan mengkur persepsi resiko yaitu : 1) financial risk; 2) product risk; 3) security risk; 4) time risk; 5) social risk; dan 6) psychological risk.

The relationship between perceived risk and purchase intention in this study refers to the results of previous research. (Kamalul Ariffin et al., 2018) that the perceived risk perception has a significant negative influence on the intention of online purchases. As is the case (Hamid et al., 2016) found the perceived risk negatively impacted the intention of purchasing consumers online. Research by (Pudaruth \& Nursing, 2017; Wingate, 2019) also found the risk had a negative and significant effect on purchasing intentions. In contrast to (Gunawan \& Huarng, 2015). which found that the perception of risk had a psychedetive effect on purchasing intentions. Based on the description of the results of previous research hypotheses compiled this research, that:

$\mathrm{H} 2$ : Perceived risk has a negatif and significant effect on purchase intention.

\section{Trust on Purchase Intention}

Trust is the knowledge and conclusions that consumers have about an object, its attributes, and benefits (Mowen, 2012). Trust as a fundamental element for the success of a relationship, without trust a relationship will not last long. Consumer confidence in various sources of information, consumers revealed that the recommended communication will run by itself to be the most trusted source of information (Schiffman \& Kanuk, 2012). From the description of experts can be concluded that trust is a consumer's knowledge of various attributes of products or services when consumers want to use and know the various benefits. With the trust in a product or service, consumers will be willing to make purchasing decisions.

Consumer trust is seen as the trust of the consumer to the seller related to the seller's good intentions, expertise and honesty or integrity of the seller. In the context of an online business this is important, as there is no interaction or direct communication between seller and buyer. Consumer confidence can create good trust in sellers and will increase consumer trends in purchasing behavior (Larasetiati \& Ali, 2019). Trust has a direct and significant effect on purchasing intentions. E-commerce vendors should focus on maintaining customer trust by developing many aspects such as e-service quality that customers directly feel (Firmansyah \& Ali, 2019). Research developed by (Pappas, 2018) using four indicators in measuring trust, including:1) Trustworthy; 2)Reliable; 3) Have high integrity; 4) Competent and knowledgeable.

The relationship between trust and purchase intention refers to the results of previous research. (Liu \& Guo, 2017) indicates that trust positively affects purchasing intentions. Mosunmola et al. (2019) also found an influence between trust and purchase intention. Then the results of the study (Kaur \& Quareshi, 2015; Marriott \& Williams, 2018) find the confidence factor has a positive effect and sgnifikan on the purchase intention. Customers have a sustainable purchase when they trust the seller (Zhao et al., 2019) and trust is an important factor in increasing interest in online shopping (Pappas, 2018). Based on the description of the results of previous research can be hypothesized:

H3 : Trust has a positive and significant effect on purchase intention.

\section{4. eWOM on Trust}


Referring to the results of the previous research which is the basis in building hypotheses in this research, namely the relationship between ewom to belief. Research model developed by (Bulut \& Karabulut, 2018) stated that the quality of eWOM and the quantity of eWOM have a positive influence on trust. Ali, (2019) The presence of promotional activities, such as social media, newspapers, billboards, eWOM and TV advertising can have a positive and significant influence on trust. Then (Abubakar \& Ilkan, 2016) eWOM positively affects trust and (Matute et al., 2016) Ewom is positive and sgnifikan can affect trust. Based on the description of the results of previous research can be hypothesized, that:

H4 : eWOM has a positive and significant effect on trust.

\section{Perceived Risk on Trust}

The relationship between perceived risk and trust in this study refers to the results of previous research. Research model developed by (Farivar et al., 2017) risk perception has a negative and significant effect on trust, where when consumers believe in a product, it will reduce the perceived risk. Silva et al., (2019) perceived risk negatively affects the ability. As for Ho et al., (2017) perceived risks have a significant effect on consumer confidence. Based on the description of the results of previous research can be hypothesized, that:

H5 : Perceived risk has a risk negative and significant effect on trust.

\section{Trust mediating Ewom on Purchase Intention}

The Trust mediated the relationship between ewom and purchase intention in this study referring to the results of previous research. Research model of the (Abubakar \& Ilkan, 2016) where the trust mediates positively between eWOM and the intention of purchasing. (Bhandari \& Rodgers, 2018) also found a positive influence between eWOM and buy interest mediated by the trust. As well as the findings of the (Matute et al., 2016) indicates that eWOM has a positive and significant effect directly and indirectly affects purchasing intentions through trust. Based on the description of the results of previous research can be compiled hypotheses, that:

H6 : Trust mediating ewom has a positive and significant effect on purchase intention.

\section{Trust mediating Perceived Risk on Purchase Intention}

Trust mediates the relationship between perceived risk and purchase intention in reference to the results of previous research. (Farivar et al., 2017) found that the risk of having a significant negative influence on purchase intention and trust has a positive influence on purchase intention. In addition, trust can reduce the perceived risk, thereby giving rise to buying interest. Similarly, research (Silva et al., 2019) found that trust in the online environment is negatively influenced by risk perception, which also affects online purchasing behavior. Research by (Ho et al., 2017) indicates that the perceived risk of the user has a significant effect on trust, leading to the decision to use. As for the research developed (Pappas, 2016; Park et al., 2019; Yang et al., 2015) the results showed that the perception of risk to trust had a significant negative effect and that trust had a positive effect on buying interest. Based on the description of the results of previous research can be compiled research hypothesis, that: 
H7 : Trust mediating perceived risk has a negative and significant effect on purchase intention.

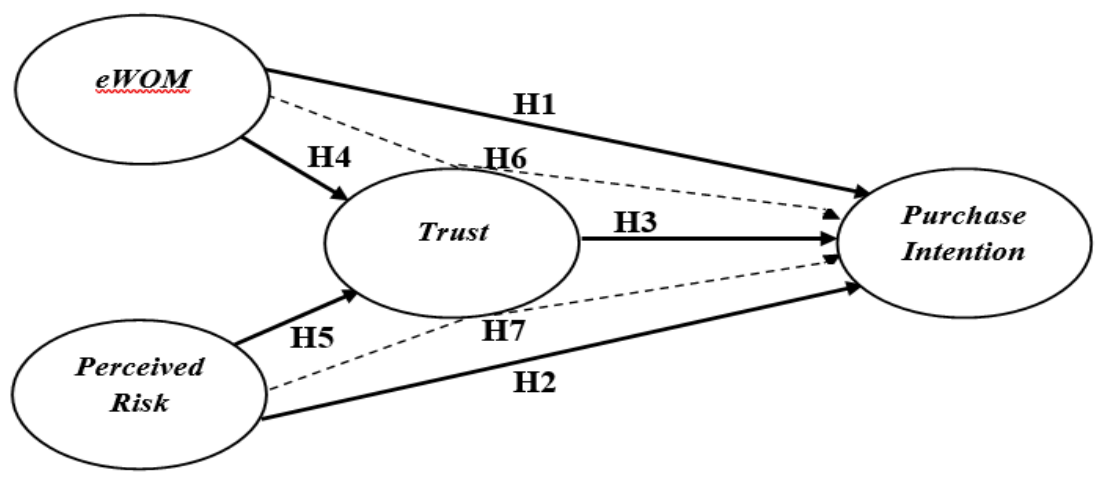

Figure 2. Conceptual Framework

\section{RESEARCH METHODS}

Shields and Rangarajan (2013) descriptive research is used to describe the characteristics of a population or phenomenon to describe the situation. The nature of the population of this study is unknown, thus using non-probability sampling with convenience sampling techniques. Data sources required for data processing using SEM-PLS require at least 10 times the independent variables of the outer model and inner model or use the concept of sample size with the number of indicators x 10 (Hair et al., 2013). The number of indicators of this research is 16 , then obtained a minimum number of 160 research samples that will be distributed to consumers who have never made an online purchase using the shopee application in DKI Jakarta.

Data analysis method using SEM method - PLS Structural Equation Model with Partial Least Square Modeling Software. There are several stages of model evaluation in PLS (Hair et al., 2013), First evaluation of measurement model (Outer Model), Second, evaluation of structural model (Inner Model) And Third, path coefficient.

\section{FINDINGS AND DISCUSSION Measurement Model Testing (Outer Model)}

Measurement model (Outer Model) test, which aims to discuss vailidity test results, reliability test, and other test results.

Validity Test. Validity is a test conducted to find out how well the instrument developed is able to measure a certain concept (Sekaran \& and Roger Bougie, 2013). The validity test results are: 1) Convergent validity measures the strength of indicators in reflecting latent constructs. If the loading factor value $\leq$ to 0.5 , then the indicator should be dropped. 
minimum for loading factor in convergent validity is 0.5 and better if the loading factor is $\geq$ 0.7 (Hair et al., 2014).

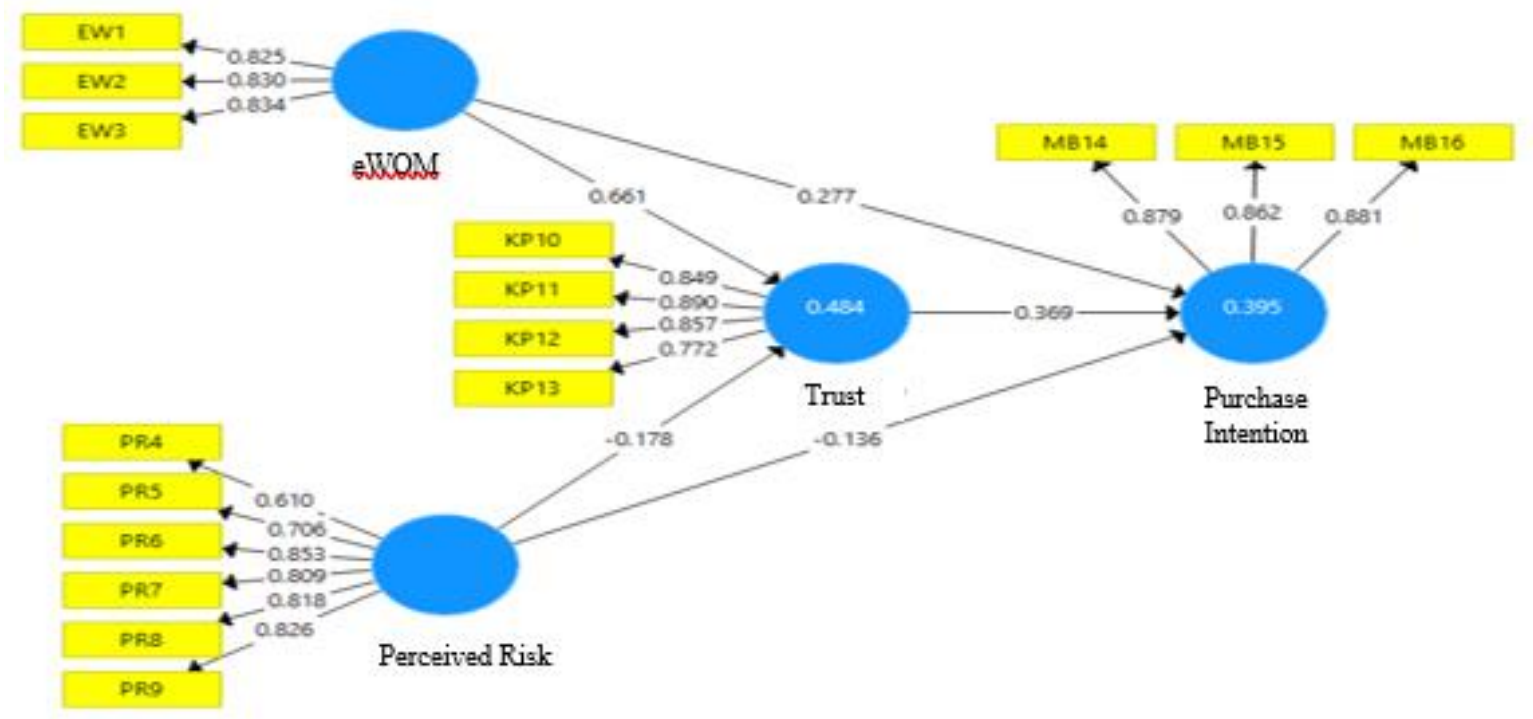

Figure 3. Value Loading Factor Using SmartPLS

Based on figure 2. it can be seen that all loading factor values of each indicator in measuring latent variables above 0.5 . This proves that all indicators are acceptable (valid) or have met convergent validity.

2) Discriminant Validity Cross Loading, is a measurement that has perinsip that in different construction measurements do not have a high correlation. The result of discriminant validity can be seen through ave (Average Varience Extracted) value. Discriminant validity to measure the accuracy of reflective models. if ave value $<0.5$ is declared invalid, whereas if AVE value $>0.5$ is declared valid (Hair et al., 2013). AVE values include: $\mathrm{eWOM}=0.688$ $>0.5$; Risk Perception $=0.601>0.5$; Trust $=0.711>0.5$; and Buy Interest $=0.764>0.5$ Ave value for all research variables declared valid, making it feasible to do the next test. Thus, Validity Test has been fulfilled where Convergent Validity, discriminant validity cros loading and AVE value can be stated to have good test criteria because the research model can be received (valid).

Reliability Test. Test reliability to find out how far a measuring instrument is reliable. Composite reliability is used to assess the internal consistency of good indicators. The minimum composite reliability number is $>0.7$ (Hair et al., 2013). The output result of outer model of composite reliability, namely: $\mathrm{eWOM}=0.869>0.7$; Perceived risk $=0.899>0.7$; Trust $=0.908>0.7$; and Purchase intention $=0.907>0.7$. Overall composite reliability value above 0.7 , can be stated that the research model has been reliable or has met the composite reliability test criteria.

Reliability testing using cronbach's alpha value. The construct is declared reliabel if cronbach's alpha value $>0.60$ (Hair et al., 2013). The result of all cronbach's alpha values above 0.6, that is: $\mathrm{eWOM}=0.775>0.6$; Perceived risk $=0.855>0.6$; Trust $=0.863>0.6$; Purchase intention $=0.846>0.6$, thus the research model is reliable or reliable. The results of 
cronbach's alpha and Composite Reliability above have been in accordance with the reliability test criteria so that it can be made a reliable and trustworthy measuring instrument.

\section{Structural Model Testing (Inner Model)}

\section{R-Square}

The R-Square value can be used to explain the influence of certain exogenous variables on endogenous. R-Square values of $0.75,0.50$, and 0.25 models are strong, moderate and weak (Ghozali \& Latan, 2015). The result of R-Square value of endogenous variable is trust $=48.4 \%$, meaning that $\mathrm{R} 2$ value can be said to be moderate where exogenous variable affects endogenous variable (trust) is medium. While the value of buying interest $=3.95 \%$, meaning that the value of $\mathrm{R} 2$ can be said to be moderate where the exogenous variable affects the endogenous variable (buy interest) is medium.

\section{Measuring Effect Size f2}

Effect Size $\mathrm{f} 2$ to find out the magnitude of the influence of exogenous variables on endogenous or to see the goodness of the model. The criteria for small magnitude are 0.02 (small), 0.15 (medium) and 0.35 (large) (Hair et al., 2013). The result of effect size (f sqare) calculation is: 1) The influence of ewom on trust 0.84 is large; 2) Ewom's influence on purchase intention of 0.07 is small; 3) The effect of perceived risk on trust 0.06 is small; 4) The effect of perceived risk on purchase intention 0.03 is small; and 5) The effect of trust on purchase intention 0.11 is to prevent,

\section{Overall Structural Model Measurement with Good of Fit index (GoF)}

GoF testing aims to validate the combined performance between (Outer model) and (inner model). The calculation result of $(\mathrm{GoF})$ shows the yield value of 0.550 . Criteria GoF small $=0.1$, medium $=0.25$ and large $=0.36$ (Ghozali \& Latan, 2015). The result of the calculation is quite good because the value $(\mathrm{GoF})$ is more than 0.36 (large scale).

Predictive Relevance Testing (Q2). The purpose of conducting predictive relevance (Q2) testing is to validate the model. With the criteria if the Q2 $>0$, the model has a predctive relevance whereas if $\mathrm{Q} 2<0$, it has less predictive relevnce. Q2 calculation result, trust variable 0.34 and purchase intention variable 0.29 which means it has predictive relevance, because Q2 value is greater than 0 .

Hypothesis testing. The results of structural model testing with coefficient test can be seen in the result of structural p-value and t-value model path coefficient. Structural model criteria use error level of $5 \%$, where if $t$-value $>1.96$ is declared significant, while if $t$-value $<1.96$ is declared insignificant or if p-value $<\mathrm{t}$-table $=0.05$ is declared significant, while $\mathrm{p}$ value $>\mathrm{t}$-table $=0.05$ is declared insignificant (Ghozali \& Latan, 2015).

Table 1. Path Coefficients results

\begin{tabular}{lcccc}
\hline Influence of the construct & $\begin{array}{c}\text { Original } \\
\text { Sample } \\
(\mathbf{O}) / \text { Beta }\end{array}$ & T Statistics & $\begin{array}{c}\text { P } \\
\text { Values }\end{array}$ & T table \\
\hline eWOM $\rightarrow$ Purchase Intention & 0.28 & 2.62 & 0.01 & $<0,05$
\end{tabular}




$\begin{array}{lcccc}\text { Perceived Risk } \rightarrow \text { Purchase Intention } & -0.14 & 2.11 & 0.04 & <0,05 \\ \text { Trust } \rightarrow \text { Purchase Intention } & 0.37 & 3.70 & 0.00 & <0,05 \\ \text { eWOM } \rightarrow \text { Trust } & 0.66 & 15.05 & 0.00 & <0,05 \\ \text { Perceived Risk } \rightarrow \text { Trust } & -0.18 & 2.72 & 0.01 & <0,05 \\ \text { eWOM } \rightarrow \text { Trust } \rightarrow \text { Purchase Intention } & 0.24 & 3.64 & 0.00 & <0,05 \\ \text { Perceived Risk } \rightarrow \text { Trust } \rightarrow \text { Purchase Intention } & -0.07 & 2.22 & 0.03 & <0,05\end{array}$

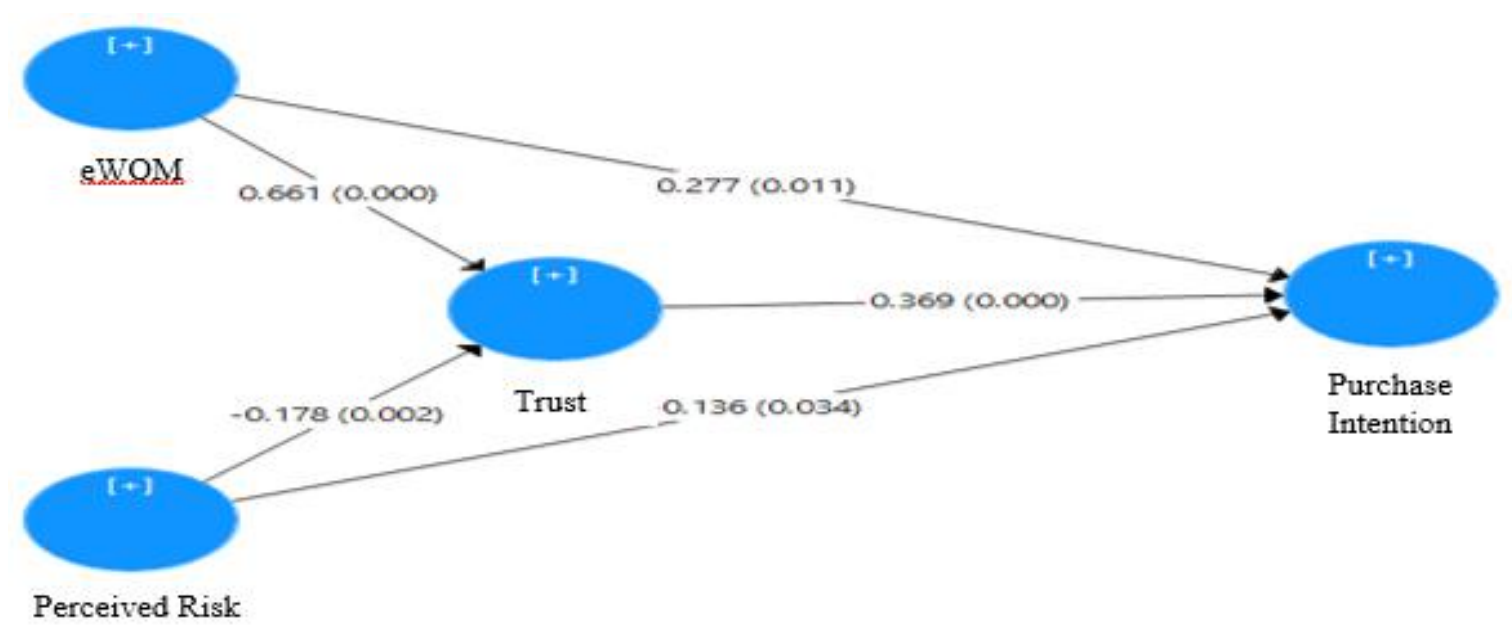

Figure 4. Results of Structural Model Coefficient of Original Sample and P-Value

\section{DISCUSSION}

\section{H1 : eWOM has a Positive and Significant Effect on Purchae Intention.}

Based on the results of the study found that ewom has a positive and significant effect on the purchase intention online in shopee. This finding is in accordance with the hypothesis built, where ewom can positively and significantly affect the purchase intention online shopee, meaning that if ewom formed from the aspect of positive online review information in large numbers, then the information provided can be trusted and the information provided is also quality then it can significantly affect the buying interest of consumers online at shopee. Where from the highest loading factor the purchase intention online at Shopee can be formed, if the consumer comments are positive and up to date. The findings of this study are in line with research by (Abubakar \& Ilkan, 2016) found that e-wom can affect purchase intention. These results correspond to the (Erkan \& Evans, 2016) ewom has a positive and significant influence on purchase intention. As is the case (Bataineh, 2015) found ewom has a positive and significant influence on purchase intention.

\section{H2 : Perceived Risk has a Negatif and Significant Effect on Purchase Intention.}


Based on the results of the study found that the perception of risk has a negative and significant effect on the online purchase intention in shopee. These findings are in accordance with the built hypothesis, where the perception of risk can negatively and significantly affect the interest in buying online shopee, meaning that when the risk perceived by consumers is lower such as the risk of price mismatch, product quality risk, security risk when transacting, the risk of product acceptance time, social risks and psychological risks can have a real effect on online purchase intention in shopee. From the highest loading factor that the risk felt by consumers will be reduced, if the security of shopping at Shopee can be increased. These findings are in accordance with the (Hamid et al., 2016) found that perceived risks negatively impact consumer purchasing intentions online. As is the case (Kamalul Ariffin et al., 2018) that persepei perceived risk has a significant negative influence on the intention of online purchases. Then research by (Pudaruth \& Nursing, 2017; Wingate, 2019; Hamdan \& Raharja, 2020) also found the risk of negative and significant effect on the purchase intention.

\section{H3 : Trust has a Positive and Significant Effect on Purchase Intention.}

Based on the results of the study found that trust has a positive and significant effect on online purchase intention in shopee. This finding is in accordance with the hypothesis built, where trust can positively and significantly affect the interest in buying online shopee, meaning that if consumer confidence can be formed through aspects such as shopee can be trusted by consumers, shopee can always be relied on by consumers, then shopee has a high responsibility and shope competent in serving consumers online, then it can significantly affect consumers' online buying interest in shopee. From the highest loading factor results, consumer confidence can be formed if the reliability of Shopee application can be improved according to consumer response or response, so that it can form a purchase intention in Shopee. These findings are in accordance with research conducted by (Liu \& Guo, 2017) with the results of the study showed that trust positively influenced the intention to buy. Then Mosunmola et al. (2019) also found an influence between trust and buying interest. As well as the results of the study (Kaur \& Quareshi, 2015; Marriott \& Williams, 2018) finding trust factors have a positive and significant effect on buying interest and trust is an important factor in increasing online shopping interest (Pappas, 2018).

\section{H4 : eWOM has a Positive and Significant Effect on Trust.}

Based on the results of the study found that ewom has a positive and significant effect on trust in shopee. These findings are in line with the built hypothesis, where ewom can positively and significantly affect shopee's online trust, meaning the more and better electronic information about shopees that can increase consumer knowledge the more real it is to increase consumer trust in shopee. From the highest loading factor results, when the latest comments that match the characteristics of the product increase, it can shape online consumer trust. These findings are in accordance with the research model developed by (Bulut \& Karabulut, 2018) stated that the quality of eWOM and the quantity of eWOM have a positive influence on trust. Ali, (2019) The presence of promotional activities, such as social media, newspapers, billboards, eWOM and TV advertising can have a positive and significant influence on trust. Then (Abubakar \& Ilkan, 2016) eWOM positively affects trust and (Matute et al., 2016) eWOM can positively and significantly affect trust.

\section{H5 : Perceived Risk has a Risk Negative and Significant Effect on Trust.}


Based on the results of the study found that the perception of risk has a negative and significant effect on trust in shopee. These findings are in accordance with the built hypothesis, where the perception of risk can negatively and significantly affect trust in the shopee, meaning that the risk that consumers perceive to shopee from the consequences received is low then can increase in real consumer trust when there is a desire to shop at the shopee. From the highest loading factor results, consumer trust will be formed when the security risk received is low. These findings are in accordance with the research model developed by (Farivar et al., 2017) perception of risk negatively and significantly affects trust, where when consumers believe in a product, it will reduce the perceived risk. Silva et al., (2019) perception of risk negatively affects the ability. As for Ho et al., (2017) perceived risks have a significant effect on consumer trust.

\section{H6 : Trust Mediating Ewom has a Positive and Significant Effect on Purchase Intention.}

Based on the results of the study found that the trust can mediate ewom positively and significantly on the online purchase intention in shopee. These findings are in line with the built hypothesis, where the trust is able to mediate ewom positively and significantly affect the online purchase intention shopee. This shows that there is consumer trust about the Shopee App, making it easier for consumers to find or get information from various relevant and reliable sources or from consumers who recommend the product, this will further increase consumer interest in shopping online at Shopee. From the highest loading factor results, if the reliability of the Shopee Application is consistent then it can form quality information, so that consumers are interested in making purchases at Shopee. These findings are in accordance with the (Abubakar \& Ilkan, 2016) where the trust mediates positively between eWOM and the intention of purchasing. (Bhandari \& Rodgers, 2018) also found a positive influence between eWOM and buy interest mediated by the trust. As well as the findings of the (Matute et al., 2016) indicates that eWOM has a positive and significant effect directly and indirectly affects purchasing intentions through trust.

\section{H7 : Trust Mediating Perceived Risk has a negative and Significant Effect on Purchase Intention.}

Based on the results of the study found that trust mediating the perception of risk has a significant negative effect on online buying interest in Shopee. These findings are in line with the built hypothesis, where trusts can mediate negatively and significantly between risk perception and online buying interest in Shopee. This indicates that when consumers believe in the Shopee App, it will further reduce the consequences that consumers receive and will ultimately increase consumer buying interest in Shopee. From the highest loading factor, if shopee app is always reliable and has high responsibility, then it can increase security when going shopping at Shopee. These findings are according to the study (Farivar et al., 2017) that the risk has a significant negative influence on buying intentions and trust has a positive influence on buying intentions. In addition, trust can reduce the perceived risk, thereby giving rise to buying interest. Similarly, research (Silva et al., 2019) finding trust in the online environment is negatively influenced by risk perception, which also affects purchasing behavior. Research (Ho et al., 2017) shows the perceived risk of users having a significant effect on trust, leading to decisions to use. As for research (Pappas, 2016; Park et al., 2019; 
Yang et al., 2015) risk perception has a significant negative effect on trust and trust has a positive effect on purchase intention.

This article examines the effect of the variables e-WOM and Purchase Intention, on Perceived Risk and Trust. Apart from these exogenous variables, there are still many other factors that affect Perceived Risk and Trust , including: 1) Brand Image: (Ali et al., 2016), (M \& Ali, 2017), (Ali \& Mappesona, 2016), (Ali, Narulita, et al., 2018), (Novansa \& Ali, 1926), and (Toto Handiman \& Ali, 2019). 2) Product Quality: (Desfiandi et al., 2017), (M \& Ali, 2017), (Ali, Narulita, et al., 2018), (M \& Ali, 2017), (Ali, Evi, et al., 2018), (Prihartono \& Ali, 2020), (Riyanto et al., 2017), (Maisah \& Ali, 2020), (Brata et al., 2017), (Thanh Nguyen et al., 2019), (Ali, 2019b), and (Anggita \& Ali, 2017). 3) Service Quality or Service Delivery : (M \& Ali, 2017), (Limakrisna \& Ali, 2016), (Yunita \& Ali, 2017), (Yunita \& Ali, 2017), (Ali \& Mappesona, 2016), (Ali, Evi, et al., 2018), (Sitio \& Ali, 2019), and (Anggita \& Ali, 2017).

\section{CONCLUSION}

Conclusions to answer the research model built.: 1) eWOM has a positive and significant influence on online purchase intention in Shopee. The more qualified information from various electoral sources towards Shopee, it can increase the online purchase intention at Shopee; 2) Perceived risk has a negative and significant influence on online purchase intention in Shopee. The reduced risk perceived to Shopee, it can increase the interest in buying online at Shopee; 3) Trust has a positive and significant influence on online purchase intention in Shopee. Increasing consumer confidence in Shopee, it can increase the interest in buying online at Shopee; 4) eWOM has a positive and significant influence on trust in Shopee. The better the reviews and information about Shopee, it can increase consumer confidence in Shopee; 5)Perceived risk has a negative and significant influence on trust in Shopee. The low risk that is perceived when you want to transact in Shopee, it can increase consumer trust in Shopee; 6) Trust is able to mediate eWOM has a positive and significant effect on online purchase intention in Shopee. The existence of strong consumer confidence will make it easier for these consumers to find and get quality information from various electronic sources about Shopee, so that it can influence the online purchase intention at Shopee; and 7) Trust is able to mediate Perceived risk negatively and significantly on online buying interest in Shopee. Consumer trust in Shopee, will lower the risk that consumers perceive to the consequences that will be received, so as to affect the online purchase intention at Shopee.

\section{MANAGERIAL IMPLICATIONS}

Managerial implications aim to provide Shopee with the right and effective marketing decision-making strategies in the future based on research findings as empirical evidence that is important for the company to implement. The following managerial implications that Shope can implement are: a) Shopee Company can form eWOM by maintaining the latest comments from consumers, so as to influence consumer interest in shopping at Shopee; b) Shopee Company can reduce the risks felt by consumers by always improving the security of shopping, so as to affect consumers' interest in shopping at Shopee; c) Shopee Company can build consumer trust by continuously improving reliability on the Shopee App, so as to influence consumers' interest in shopping at Shopee; d) Shopee Company can form consumer trust by keeping comments updated and quality information from various sources; e) Shopee Company can build consumer trust by increasing transaction security and always making innovations that 
can make consumers happy to shop online; f) Shopee Company must be able to provide reliability in service and various features, so as to create information and recommendations to consumers that impact the willingness of consumers to continue to be interested in making purchases at Shopee; and g) Shopee Company should be able to provide reliability in services and various features, and also increase security when consumers shop online at Shopee, because it can create an interest in buying online on an ongoing basis.

\section{ACADEMIC IMPLICATIONS}

This research has limitations that can be used as advice or input for further research. This research uses SEM-PLS data analysis method, for research selanjutanya can use other data analysis methods. Then the next research can use the linkages between the factors in this study to be fundamentally reviewed, because based on the results of the determination test (R Square) still does not meet the test criteria either. This is because several other factors outside the research have an influence on online buying interest in Shopee. Then the lowest loading factor value of all indicators used is financial risk which is an indicator of risk perception with a value of 0.6. Therefore, it is necessary to consider other factors as exogenous variables that are considered important to be studied, such as: ease of transaction, e-social influence, and product attributes. As for endogenous variables can use purchasing decisions and repurchases.

\section{REFERENCE}

Abubakar, A. M., \& Ilkan, M. (2016). Impact of online WOM on destination trust and intention to travel: A medical tourism perspective. Journal of Destination Marketing and Management, 5(3), 192-201. https://doi.org/10.1016/j.jdmm.2015.12.005

Ali dan Tonny Wangdra, H. (2010). Technopreneurship dalam Perspektif Bisnis Online. 45.

Ali, H. (2019a). Building Repurchase Intention and Purchase Decision: Brand Awareness and Brand Loyalty Analysis (Case Study Private Label Product in Alfamidi Tangerang). Saudi Journal of Humanities and Social Sciences, 04(09), 623-634. https://doi.org/10.36348/sjhss.2019.v04i09.009

Ali, H. (2019b). Purchase Decision and Repurchase Models: Product Quality and Process Analysis (Case Study of House Ownership Credit Financing in Permata Sharia Bank Jakarta). Scholars Bulletin. https://doi.org/10.36348/sb.2019.v05i09.006

Ali, H., Evi, N., \& Nurmahdi, A. (2018). The Influence of Service Quality , Brand Image and Promotion on Purchase Decision at MCU Eka Hospital. Business and Management Studies. https://doi.org/10.21276/sjbms.2018.3.1.12

Ali, H., Limakrisna, N., \& Jamaluddin, S. (2016). Model of customer satisfaction: The empirical study at Bri in Jambi. International Journal of Applied Business and Economic Research.

Ali, H., \& Mappesona, H. (2016). Build brand image: Analysis Service Quality and Product Quality (case study at Giant Citra Raya). International Journal of Economic Research.

Ali, H., Narulita, E., \& Nurmahdi, A. (2018). Saudi Journal of Business and Management Studies ( SJBMS ) The Influence of Service Quality, Brand Image and Promotion on Purchase Decision at MCU Eka Hospital. Business and Management Studies. https://doi.org/10.21276/sjbms.2018.3.1.12

Anggita, R., \& Ali, H. (2017). The Influence of Product Quality, Service Quality and Price to Purchase Decision of SGM Bunda Milk (Study on PT. Sarihusada Generasi Mahardika Region Jakarta, South Tangerang District). Scholars Bulletin. 
https://doi.org/10.21276/sb

Arce-Urriza, M., Cebollada, J., \& Tarira, M. F. (2017). The effect of price promotions on consumer shopping behavior across online and offline channels: differences between frequent and non-frequent shoppers. Information Systems and E-Business Management, 15(1), 69-87. https://doi.org/10.1007/s10257-016-0310-2

Baron, R. M., \& Kenny, D. A. (1986). The Moderator-Mediator Variable Distinction in Social Psychological Research. Conceptual, Strategic, and Statistical Considerations. Journal of Personality and Social Psychology, 51(6), 1173-1182. https://doi.org/10.1037/0022-3514.51.6.1173

Bataineh, A. Q. (2015). The Impact of Perceived e-WOM on Purchase Intention: The Mediating Role of Corporate Image. International Journal of Marketing Studies, 7(1), 126-137. https://doi.org/10.5539/ijms.v7n1p126

Bhandari, M., \& Rodgers, S. (2018). What does the brand say? Effects of brand feedback to negative eWOM on brand trust and purchase intentions. International Journal of Advertising, 37(1), 125-141. https://doi.org/10.1080/02650487.2017.1349030

Brata, B. H., Husani, S., \& Ali, H. (2017). The Importance of Quality Products, Price, Promotion, and Location to Product Purcese Decision on Nitchi At PT. Jaya Swarasa Agung in Central Jakarta. Saudi Journal of Business and Management Studies. https://doi.org/10.21276/sjbms

Bulut, Z. A., \& Karabulut, A. N. (2018). Examining the role of two aspects of eWOM in online repurchase intention: An integrated trust-loyalty perspective. Journal of Consumer Behaviour, 17(4), 407-417. https://doi.org/10.1002/cb.1721

Desfiandi, A., Fionita, I., \& Ali, H. (2017). Implementation of the information systems and the creative economy for the competitive advantages on tourism in the province of Lampung. International Journal of Economic Research.

Dodi, P. (2017). Toward the Best Model of Strategy Implementation in Indonesian Islamic Banking from the Lens of Strategic Clarity. European Research Studies Journal, $X X(4 \mathrm{~B}), 3-15$.

Erkan, I., \& Evans, C. (2016). The influence of eWOM in social media on consumers' purchase intentions: An extended approach to information adoption. Computers in Human Behavior, 61, 47-55. https://doi.org/10.1016/j.chb.2016.03.003

Farivar, S., Turel, O., \& Yuan, Y. (2017). A trust-risk perspective on social commerce use: an examination of the biasing role of habit. Internet Research, 27(3), 586-607. https://doi.org/10.1108/IntR-06-2016-0175

Firmansyah, N., \& Ali, H. (2019). Consumer Trust Model : The Impact of Satisfaction and EService Quality toward Repurchase Intention in E-Commerce. 6256, 552-559. https://doi.org/10.21276/sjhss.2019.4.8.4

Gunawan, D. D., \& Huarng, K. H. (2015). Viral effects of social network and media on consumers' purchase intention. Journal of Business Research, 68(11), 2237-2241. https://doi.org/10.1016/j.jbusres.2015.06.004

Hair, J. F., Ringle, C. M., \& Sarstedt, M. (2013). Partial Least Squares Structural Equation Modeling: Rigorous Applications, Better Results and Higher Acceptance. Long Range Planning, 46(1-2), 1-12. https://doi.org/10.1016/j.lrp.2013.01.001

Hamdan, H., \& Raharja, I. (2020). Peran Product Knowledge Terhadap Persepsi Risiko Minuman Kekinian. Jurnal Ilmu Manajemen Terapan, 2(1), 128-141. https://doi.org/10.31933/jimt.v2i1.314

Ho, S. M., Ocasio-Velázquez, M., \& Booth, C. (2017). Trust or consequences? Causal effects 
of perceived risk and subjective norms on cloud technology adoption. Computers and Security, 70, 581-595. https://doi.org/10.1016/j.cose.2017.08.004

Indrajaya, H. S., \& Al, H. (2017). Shopping Analysis in on Line Shop with Young People. The International Journal of Social Sciences and Humanities Invention, 4(7), 37973802. https://doi.org/10.18535/ijsshi/v4i8.17

Jalilvand, M. R., Nasrolahi Vosta, L., Kazemi Mahyari, H., \& Khazaei Pool, J. (2017). Social responsibility influence on customer trust in hotels: mediating effects of reputation and word-of-mouth. Tourism Review, 72(1), 1-14. https://doi.org/10.1108/TR-09-2016-0037

Kamalul Ariffin, S., Mohan, T., \& Goh, Y. N. (2018). Influence of consumers' perceived risk on consumers' online purchase intention. Journal of Research in Interactive Marketing, 12(3), 309-327. https://doi.org/10.1108/JRIM-11-2017-0100

Larasetiati, M., \& Ali, H. (2019). Model of Consumer Trust: Analysis of Perceived Usefulness and toward Repurchase Intention in Online Travel Agent. Journal of Economics and Finance, 3(8), 350-357. https://doi.org/10.21276/sjef.2019.3.8.5

Lecturer, M. H. (2016). Impact of website design and Perceived Risk, Internet trust on the Consumer Purchase intention in FOREX Market. 2(2).

Lee, W. I., Cheng, S. Y., \& Shih, Y. T. (2017). Effects among product attributes, involvement, word-of-mouth, and purchase intention in online shopping. Asia Pacific Management Review, 22(4), 223-229. https://doi.org/10.1016/j.apmrv.2017.07.007

Limakrisna, N., \& Ali, H. (2016). Model of Customer Satisfaction: Empirical Study At Fast Food Restaurants in Bandung. International Journal of Business and Commerce.

Liu, D., \& Guo, X. (2017). Can trust and social benefit really help? Empirical examination of purchase intentions for wearable devices. Information Development, 33(1), 43-56. https://doi.org/10.1177/0266666916635724

M, A., \& Ali, H. (2017). MODEL KEPUASAN PELANGGAN: ANALISIS KUALITAS PRODUK DAN KUALITAS LAYANAN TERHADAP CITRA MEREK PADA GIANT CITRA RAYA JAKARTA. Jurnal Manajemen. https://doi.org/10.24912/jm.v21i3.254

Maisah, \& Ali, H. (2020). Entrepreneurship culture development process: Implementation of Islamic education values in the Batik Jambi (case study in Seberang Jambi community). Talent Development and Excellence.

Marriott, H. R., \& Williams, M. D. (2018). Exploring consumers perceived risk and trust for mobile shopping: A theoretical framework and empirical study. Journal of Retailing and Consumer Services, 42(January), 133-146. https://doi.org/10.1016/j.jretconser.2018.01.017

Matute, J., Polo-Redondo, Y., \& Utrillas, A. (2016). The influence of EWOM characteristics on online repurchase intention. Online Information Review, 40(7), 1090-1110. https://doi.org/10.1108/oir-11-2015-0373

Mosunmola, A., Adegbuyi, O., Kehinde, O., Agboola, M., \& Olokundun, M. (2019). Percieved value dimensions on online shopping intention: The role of trust and culture. Academy of Strategic Management Journal, 18(1), 1-20.

Novansa, H., \& Ali, H. (1926). Purchase Decision Model: Analysis of Brand Image, Brand Awareness and Price (Case Study SMECO Indonesia SME products). Saudi Journal of Humanities and Social Sciences. https://doi.org/10.21276/sjhss

Pappas, I. O. (2018). User experience in personalized online shopping: a fuzzy-set analysis. European Journal of Marketing, 52(7-8), 1679-1703. https://doi.org/10.1108/EJM-10- 
2017-0707

Pappas, N. (2016). Marketing strategies, perceived risks, and consumer trust in online buying behaviour. Journal of Retailing and Consumer Services, 29, 92-103. https://doi.org/10.1016/j.jretconser.2015.11.007

Park, J., Amendah, E., Lee, Y., \& Hyun, H. (2019). M-payment service: Interplay of perceived risk, benefit, and trust in service adoption. Human Factors and Ergonomics In Manufacturing, 29(1), 31-43. https://doi.org/10.1002/hfm.20750

Prihartono, \& Ali, H. (2020). The promises ethics and marketing concept strategy as a competitive advantage on private higher education (A survey on perception of product attributes and promotion mix in Indonesia). Talent Development and Excellence.

Pudaruth, S., \& Nursing, R. K. (2017). Exploring the Determining Factors Influencing Online Purchase Behaviour Among Consumers in Emerging Economies : a Case of Mauritius. International Journal of Arts \& Science, 10(01), 1-22.

Rahman, M. A., Islam, A., Esha, B. H., Sultana, N., \& Chakravorty, S. (2018). Cogent Business \& Management Consumer buying behavior towards online shopping : An empirical study on Dhaka city , Bangladesh Consumer buying behavior towards online shopping : An empirical study on Dhaka city ,. Cogent Business \& Management, 5(1), 1-22. https://doi.org/10.1080/23311975.2018.1514940

Riyanto, S., Adila, L., \& Ali, H. (2017). The Effect of Incentives And Job Enthusiasm To Productivity of Go-Jek Driver At PT . Go-Jek Indonesia. Journal of Research in Business and Management.

Silva, J., Pinho, J. C., Soares, A., \& Sá, E. (2019). Antecedents of online purchase intention and behaviour: Uncovering unobserved heterogeneity. Journal of Business Economics and Management, 20(1), 131-148. https://doi.org/10.3846/jbem.2019.7060

Sitio, T., \& Ali, H. (2019). Patient Satisfaction Model and Patient Loyalty: Analysis of Service Quality and Facility (Case Study at Rawamangun Special Surgery Hospital). Scholars Bulletin. https://doi.org/10.36348/sb.2019.v05i10.002

Suharjadi, P. D., Pascasarjana, P., Manajemen, M., \& Mercu, U. (2017). Jurnal SWOT, Volume VII , No 3 , September 2017 Jurnal SWOT, Volume VII , No 3 , September 2017. VII(3), 629-645.

Suryana, S. (2010). Metodologi Penelitian. Universitas Pendidikan Indonesia, 58. https://doi.org/10.1007/s13398-014-0173-7.2

Thanh Nguyen, P., Ali, H., \& Agung Hudaya. (2019). MODEL BUYING DECISION AND REPEAT PURCHASE: PRODUCT QUALITY ANALYSIS (Case Study of Bank Permata Syariah Jakarta KPR Financing Customers). Dinasti International Journal of Management Science. https://doi.org/10.31933/dijms.v1i1.29

Toto Handiman, U., \& Ali, H. (2019). The Influence of Brand Knowledge and Brand Relationship On Purchase Decision Through Brand Attachment. In International Journal of Business Marketing and Management (IJBMM).

Wingate, N. (2019). The Influence of Fake Reviews on Consumer Perceptions of Risks and Purchase Intentions. Journal of Marketing Development and Competitiveness, 13(3), 133-144. https://doi.org/10.33423/jmdc.v13i3.2244

Yang, Q., Pang, C., Liu, L., Yen, D. C., \& Michael Tarn, J. (2015). Exploring consumer perceived risk and trust for online payments: An empirical study in China's younger generation. Computers in Human Behavior, 50, 9-24. https://doi.org/10.1016/j.chb.2015.03.058

Yunita, D., \& Ali, H. (2017). Model of Purchasing Decision ( Renting ) of Generator Set: 
Analysis of Product Quality, Price an Service at PT . Hartekprima Listrindo.

Economics, Business and Management. https://doi.org/10.21276/sjebm.2017.4.11.12

Zhao, J. Di, Huang, J. S., \& Su, S. (2019). The effects of trust on consumers' continuous purchase intentions in $\mathrm{C} 2 \mathrm{C}$ social commerce: A trust transfer perspective. Journal of Retailing and Consumer Services, 50(January), 42-49.

https://doi.org/10.1016/j.jretconser.2019.04.014 